\title{
Stage II Nasopharyngeal Carcinoma AJCC v8
}

National Cancer Institute

\section{Source}

National Cancer Institute. Stage II Nasopharyngeal Carcinoma A/CC v8. NCI Thesaurus.

Code C132818.

Stage II includes: (T1, N1, M0); (TO, N1, M0); (T2, N0, M0); (T2, N1, M0). T1: Tumor confined to the nasopharynx, or tumor extending to oropharynx and/or nasal cavity without parapharyngeal involvement. T0: No tumor identified, but EBV-positive cervical node(s) involvement is present. T2: Tumor with extension to parapharyngeal space, and/or adjacent soft tissue involvement (medial pterygoid, lateral pterygoid, prevertebral muscles). N0: No regional lymph node metastasis. N1: Tumor with unilateral metastasis in cervical lymph node(s), and/or unilateral or bilateral metastasis in retropharyngeal lymph node(s), $6 \mathrm{~cm}$ or smaller in greatest dimension, above the caudal border of cricoid cartilage. M0: No distant metastasis. (AJCC 8th ed.) 